\title{
Composition of the Families of Parasitoids Wasp in the Parque Nacional da Serra da Canastra, Minas Gerais,
} Brazil

\author{
Diego Galvão Pádua ${ }^{\bowtie}$, Sônia Lúcia Modesto Zampieron² \& Juliano Fiorelini Nunes ${ }^{2}$
}

1. Instituto Nacional de Pesquisas da Amazônia, e-mail: paduadg@gmail.com (Autor para correspondência ${ }^{\varpi}$ ). 2. Fundação de Ensino Superior de Passos, e-mail: sonia.zampieron@gmail.com, fiorelini@gmail.com.

\section{EntomoBrasilis 7 (3): 199-206 (2014)}

Abstract. This study aimed to produce an inventory of the parasitoid Hymenoptera for the Parque Nacional da Serra da Canastra, using the vegetation sweep method. Between September 2009 the October 2010, 6,489 exemplars were collected, belonging to eight superfamilies and 24 families. Eulophidae, Braconidae, Platygastridae, Pteromalidae and Encyrtidae were the families with the highest relative abundance, being responsible for $18.6 \%, 18.5 \%, 15.8 \%, 10.3 \%$, and $9.8 \%$ the total number of collected, respectively. Nineteen families combined contributed less than $4 \%$ of the sample. The greatest diversity occurred at sample points located on the base of the Chapadão da Canastra, influenced, probably, by the phytophysiognomic gradient in this region. A similarity analysis this study with other surveys of parasitoid wasps in the Cerrado, besides a preliminary table of Pimplinae (Ichneumonidae) genus is presented.

Keywords: Cerrado; inventory; parasitoid wasp; Pimplinae; sweeping

\section{Composição de Famílias de Vespas Parasitoides no Parque Nacional da Serra da Canastra, Minas Gerais, Brasil}

Resumo. O objetivo deste estudo foi verificar a composição faunística de Hymenoptera parasitoide do Parque Nacional da Serra da Canastra, utilizando o método de varredura de vegetação. Foram coletadas no período de setembro de 2009 a outubro de 2010 , um total de 6.489 exemplares, pertencentes a oito superfamílias e 24 famílias. Eulophidae, Braconidae, Platygastridae, Pteromalidae, Encyrtidae foram as famílias com a maior abundância relativa, sendo responsáveis por $18,6 \%, 18,5 \%, 15,8 \%, 10,3 \%$ e 9,8\% do número total coletado, respectivamente. Dezenove famílias combinadas tiveram abundancia menor que $4 \%$. As maiores diversidades foram observadas nos pontos localizados na base do chapadão da Canastra, influenciadas, provavelmente, pelo gradiente fitofisionômico desta região. Uma análise de similaridade entre este estudo com outros inventários de vespas parasitoides no Cerrado, além de uma tabela preliminar de gêneros de Pimplinae (Ichneumonidae) é apresentada.

Palavras-Chave: Cerrado; inventário; Pimplinae; varreduras vegetação; vespas parasitoides

$\int[$ n Brazil faunal surveys of families of parasitoid Hymenoptera mostly occur in either agricultural systems (e.g. DALL'OGLIO et al. 2000; РеRioto et al. (2002a, 2002b); РеRioto et al. 2004; Souza et al. 2006; Dorfey et al. 2011; FERREIRA et al. 2013) or protected areas (e.g. Azevedo \& Santos 2000; Azevedo et al. 2002; 2003; PERIOTO et al. 2003; 2005; 2008; AlenCAR et al. 2007; FeITOSA et al. 2007).

The Cerrado is often classified in accounts of world vegetation as a "savanna" (e.g. Hills \& RANDALL 1968), and in a very wide sense of that much-abused word it is. However, it is found in almost the whole possible range of structural forms: forest (with closed tree canopy), arboreal woodland (with open tree canopy), tree and scrub woodland (trees more scattered and sharing prominence with scrub elements, all woody plants together forming an open layer), closed scrub open scrub, grassland with scattered low shrubs only (the last three "savanna" in the strict structural sense), and grassland without any evidently visible woody plants (EITEN 1972).

The Parque Nacional Serra da Canastra is the second largest protected area in the state of Minas Gerais. It contributes approximately $3.9 \%$ of the 5.2 million hectares of Cerrado protected within federal conservation units (Mма/Івама 2005), and is now a major tourist attraction. The park was set up to preserve the water quality of the headwaters of the São Francisco River, as well conserve as the region's flora and fauna, which has many endemic species (IBDF 1981).

To date, a few were the surveys of insect fauna in the region, which alone justifies the need to intensify the studies, that not only will make public the biological species diversity place, as contribute with to public agencies that require local data to implement environmental protection policies.

Abreu \& ZAMPIERon (2009) conducted a pioneering study of the parasitic Hymenoptera fauna of the Parque Nacional Serra da Canastra (PNSC). At a single site they used two types of traps: Malaise and Moericke. Subsequently, PáduA \& ZAMPIERon (2012) using the vegetation sweeping method sampled the Serra da Babilônia tableland, an area within the park buffer zone still that suffers extensive human impact.

Accordingly, aim of this study was to conduct a broad-scale assessment of the faunal composition of parasitoid Hymenoptera of the Parque Nacional Serra da Canastra.

\section{MATERIALS AND METHODS}

Created by Decree No. 70,355 of April 3, 1973, Parque Nacional Serra da Canastra covers an area of approximately 200,000 hectares, across the municipalities of São Roque de Minas,

Funding Agency: CNPq, (Proc.100538/2009-6) 
T Vargem Bonita, Sacramento, Delfinópolis, Capitólio and São João Batista do Glória, Minas Gerais. The climate is tropical seasonal, with a temperate dry winter $\left(22-23^{\circ} \mathrm{C}\right)$, and an average annual rainfall of between 1,200 and 1,800 mm (Mма/Iвама 2005).

The predominant vegetation is Cerrado, with varied sub-types such as: mesophyllic hill forest, cerrado sensu stricto, grassland cerrado, rock-dominated areas and gallery forests. Altitude ranges from 800-1,500 m (IвDF 1981).

The survey was conducted at four sample points within the park, with two points at high elevations in the Chapadão da Canastra (Mma/Iвama 2005), and two points lower down, near the Casca D'anta waterfall (Figure 1).

Sample point I ( $20^{\circ} 13^{\prime}$ oo.6”S; $46^{\circ} 28^{\prime} 38.4$ ”W) was at an altitude of 1462 meters, and was in grass-dominated vegetation on a rockstrewn plain, rocky outcrops were numerous and there was a high incidence of wind. The site was some $35 \mathrm{~km}$ from Point II.

Sample point II ( $20^{\circ} 08^{\prime} 20.2$ "S; $46^{\circ} 47^{\prime} 20.4$ "W) was at an altitude of $1353 \mathrm{~m}$, and located on an ecotone between Cerrado grassland and a forest fragment located in depression. It also has a high incidence of wind and was $34 \mathrm{~km}$ from Point III.

Sample point III $\left(20^{\circ} 18^{\prime} 48.4^{\prime \prime S}\right.$; $\left.046^{\circ} 31^{\prime} 46.1^{\prime \prime W}\right)$, was located at the base of the plateau and was in an area outside the Park. It had an altitude of $854 \mathrm{~m}$, and here the sweeping method was performed in the ecotone between a formation of Cerrado sensu stricto and grassland. This Point was also close $(150 \mathrm{~m})$ to riparian vegetation on the banks of the São Francisco River. It was approximately one kilometer from Point IV.

Sample point IV ( $20^{\circ} 18^{\prime} 27.3$ ”S; $046^{\circ} 31^{\prime} 28.9$ "W), was also located at the base of the plateau, in dense riparian vegetation, with both cerrado sensu stritu and anthropogenically-disturbed areas such as roads and houses close-by. The altitude was $920 \mathrm{~m}$. It was 12 $\mathrm{km}$ distant from point I.

The sampling was done by the vegetation sweeping method, simultaneously using four sweep nets each with $43 \mathrm{~cm}$ circumference coupled with a cotton fabric, supported by an 18.5 cm cord.
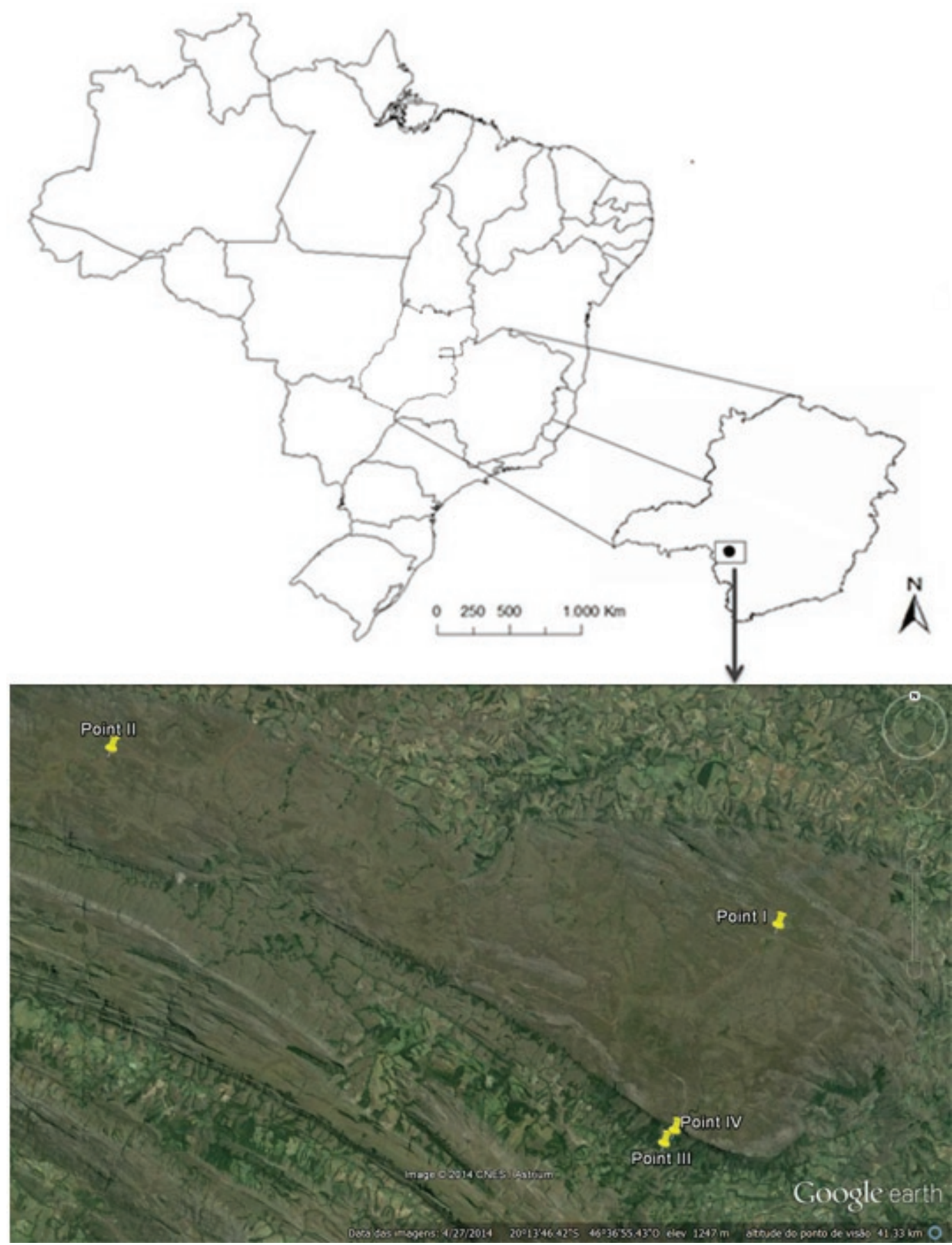

Figura 1. Location of the points in the Parque Nacional da Serra da Canastra. 
Sampling was carried out between September 2009 and October 2010, and totaled 45 samples sweepings from all four sites. Each monthly sample was a result of 15 minutes of simultaneous collection effort, by four people (total excluding time for stops to removal of collected material). The technique was applied randomly to vegetation from ground level to a height of approximately two meters. During data collection, the insects captured were transferred to killing bags containing cotton pads soaked in ethyl acetate, so as to fix the material collected. Sample collection was influenced by rainfall, hence collecting did not occur in October/2009 and March 2010, while in December 2009 and February 2010 sampling occurred on wet vegetation, which reduced capture efficiency (Table 1).

All the material was screened in the Entomology Laboratory of the Fundação de Ensino Superior de Passos (FESP), Minas Gerais. Being included the families pertaining to the series "Parasitic" (Terebrantia) and superfamily Chrysidoidea (Aculeata) followed the identification and classification of SHARKEY (2007). All material was preserved in vials with $70 \%$ alcohol, with the exception of Pimplinae which were mounted on entomological pins and identified according to GAULD (1991), with identifications subsequently checked by an expert (see acknowledgements).

The wet collections were deposited in the Entomology Laboratory of the Fundação de Ensino Superior de Passos (FESP), Minas Gerais, and pimplinids were deposited in the Entomological Collection DCBU the Federal University of São Carlos (UFSCar), São Paulo.

To calculate relative abundance we used the formula $A R=n / N$ $\mathrm{x}$ 100, where $\mathrm{n}=$ number of individuals of each family, $\mathrm{N}=$ total number of individuals collected. To create Dominance (D), Shannon diversity (H') and Equitability (J') indices the program PAST 2.00 (HAMmER et al. 2001) was used. To check the similarity between areas on the faunal composition was used the Jaccard index (C) (Southwood 1978) obtained by the program R, version 3.1.o (R Development Core Team 2014), using the package Vegan (OKSANEN et al. 2013).

\section{RESULTS AND DISCUSSION}

A total of 6,489 exemplars of parasitoid wasps were collected, in eight superfamilies and 24 families (Table 1). Three Pimplinae genera (Table 2) were also identified.

Neotheronia, Pimpla and Zonopimpla were genera of pimplineds collected in this study, through the sweeping technique. Neotheronia species are mainly idiobionts parasitoids of pupae and prepupae in cocooned lepidopteran and/or hyperparasitoids of Ichneumonidae and Tachinidae parasitoids of such hosts. Pimpla species are idiobionts endoparasitoids of pupae lepidopteran concealed in leaf litter, moss, leaf rolls in herbaceous vegetation or in the soil (GAULD et al. 1998). Zonopimpla species are solitary parasitoids or gregarious of pupae and prepupae of holometabolous insects concealed in leaf mines, galls or cocooned (GAULD 1991).

In comparison, Kumagai (2002) collected a total of 13 genera of the same subfamily at the Ecological Station of Universidade Federal de Minas Gerais/MG, using a Malaise trap, in which the three genera cited in this study, was also captured. Traditional collecting methods involving simple hand-netting, supplemented by sweeping, will produce reasonable numbers of pimplines and other ichneumonoids, especially in warm overcast weather. However, Malaise traps, is probably the best means of obtaining large, general samples from most habitats (FITTON et al. 1988).

The sweepings made at the base of the plateau collected 4,583 individuals, whereas that the specimens collected in the high part totaled 1,906 individuals. This must be related to the structural difference of the vegetation characteristic of high part, where there is high incidence of winds and the campestral formation of Cerrado is predominant, with isolated patches of forest. Unlike the base of the plateau, where the incidente of winds is less constant and structural complexity of vegetation is larger, with formation of Cerrado with more strata and major influence of river and riparian vegetation.

Table 1. Superfamilies and families of parasitoid wasps sampled by means of sweep net in the Parque Nacional da Serra da Canastra/MG in the period of September/2009 to October/2010.

\begin{tabular}{|c|c|c|c|c|c|c|c|c|c|c|c|c|c|c|}
\hline Superfamily & Family & S/o9 & N/o9 & D/o9 & $\mathrm{J} / \mathbf{1 0}$ & F/10 & A/10 & $\mathbf{M} / \mathbf{1 0}$ & $\mathrm{J} / \mathbf{1 0}$ & $\mathrm{J} / \mathbf{1 0}$ & A/10 & $\mathrm{S} / 10$ & $\mathbf{0} / \mathbf{1 0}$ & Total \\
\hline \multirow[t]{3}{*}{ Ceraphronoidea } & & 11 & o & 0 & 9 & 0 & 19 & 13 & 25 & 16 & 6 & 8 & 27 & 134 \\
\hline & Ceraphronidae & 9 & o & o & 9 & o & 19 & 13 & 24 & 16 & 6 & 7 & 27 & 130 \\
\hline & Megaspilidae & 2 & o & o & o & o & o & o & 1 & o & o & 1 & o & 4 \\
\hline \multirow[t]{15}{*}{ Chalcidoidea } & & 299 & 97 & 9 & 185 & 7 & 498 & 354 & 640 & 263 & 198 & 412 & 383 & 3345 \\
\hline & Agaonidae & o & o & o & o & o & o & o & 1 & o & o & 1 & 1 & 3 \\
\hline & Aphelinidae & 3 & o & o & o & o & 4 & 16 & 49 & 3 & o & 5 & 6 & 86 \\
\hline & Chalcididae & 22 & 5 & o & 5 & 1 & 5 & 9 & 10 & 5 & 8 & 10 & 6 & 86 \\
\hline & Encyrtidae & 44 & 14 & o & 11 & 2 & 71 & 74 & 144 & 73 & 43 & 94 & 68 & 638 \\
\hline & Eucharitidae & 3 & 3 & o & 5 & o & 5 & 2 & 5 & o & 1 & 5 & o & 29 \\
\hline & Eulophidae & 141 & 38 & 4 & 73 & 2 & 195 & 137 & 236 & 79 & 70 & 101 & 133 & 1209 \\
\hline & Eupelmidae & 16 & 3 & o & 8 & o & 9 & 16 & 22 & 11 & 5 & 14 & 18 & 122 \\
\hline & Eurytomidae & 36 & 16 & 4 & 13 & o & 40 & 23 & 28 & 13 & 15 & 24 & 38 & 250 \\
\hline & Mymaridae & 7 & 4 & o & 3 & o & 11 & 12 & 18 & 4 & 7 & 13 & 22 & 101 \\
\hline & Perilampidae & 7 & 6 & o & o & o & 1 & 1 & 1 & o & 1 & 3 & 2 & 22 \\
\hline & Pteromalidae & 10 & 1 & o & 58 & 2 & 146 & 49 & 100 & 63 & 39 & 125 & 74 & 667 \\
\hline & Signiphoridae & 1 & 1 & o & o & o & 2 & 4 & 8 & 4 & 3 & 9 & 5 & 37 \\
\hline & Torymidae & 6 & 6 & 1 & 6 & o & 2 & 5 & 14 & o & 2 & 3 & 3 & 48 \\
\hline & Trichogrammatidae & 3 & o & o & 3 & o & 7 & 6 & 4 & 8 & 4 & 5 & 7 & 47 \\
\hline Chrysidoidea & & 12 & 12 & 2 & 21 & o & 10 & 10 & 36 & 14 & 7 & 14 & 10 & 137 \\
\hline
\end{tabular}


Table 1. Continued...

\begin{tabular}{|c|c|c|c|c|c|c|c|c|c|c|c|c|c|c|}
\hline Superfamily & Family & S/O9 & N/o9 & D/o9 & $\mathrm{J} / \mathbf{1 0}$ & F/10 & A/10 & $\mathbf{M} / \mathbf{1 0}$ & $\mathbf{J} / \mathbf{1 0}$ & $\mathrm{J} / \mathbf{1 0}$ & A/10 & S/10 & $\mathbf{0} / \mathbf{1 0}$ & Total \\
\hline & Bethylidae & 12 & 10 & 1 & 21 & o & 9 & 8 & 32 & 11 & 7 & 13 & 10 & 137 \\
\hline & Dryinidae & o & 2 & 1 & o & o & 1 & 2 & 4 & 3 & o & 1 & 17 & 155 \\
\hline \multirow[t]{2}{*}{ Cynipoidea } & & o & 25 & 4 & 15 & 2 & 34 & 14 & 20 & 4 & 6 & 3 & 10 & 137 \\
\hline & Figitidae & o & 25 & 4 & 15 & 2 & 34 & 14 & 20 & 4 & 6 & 3 & 10 & 137 \\
\hline \multirow[t]{2}{*}{ Diaprioidea } & & 28 & 22 & 3 & 19 & o & 30 & 10 & 30 & 21 & 3 & o & 8 & 174 \\
\hline & Diapriidae & 28 & 22 & 3 & 19 & o & 30 & 10 & 30 & 21 & 3 & o & 8 & 174 \\
\hline \multirow[t]{2}{*}{ Evanioidea } & & 28 & 7 & 1 & 6 & o & 3 & o & 3 & 1 & 1 & 2 & 8 & 60 \\
\hline & Evaniidae & 28 & 7 & 1 & 6 & o & 3 & o & 3 & 1 & 1 & 2 & 8 & 60 \\
\hline \multirow[t]{3}{*}{ Ichneumonoidea } & & 254 & 197 & 25 & 127 & 31 & 178 & 105 & 181 & 100 & 65 & 126 & 69 & 1458 \\
\hline & Braconidae & 191 & 156 & 20 & 105 & 27 & 157 & 94 & 143 & 90 & 53 & 109 & 58 & 1203 \\
\hline & Ichneumonidae & 63 & 41 & 5 & 22 & 4 & 21 & 11 & 38 & 10 & 12 & 17 & 11 & 255 \\
\hline \multirow[t]{2}{*}{ Platygastroidea } & & 159 & 45 & 1 & 84 & 2 & 166 & 94 & 145 & 69 & 46 & 77 & 138 & 1026 \\
\hline & Platygastridae & 159 & 45 & 1 & 84 & 2 & 166 & 94 & 145 & 69 & 46 & 77 & 138 & 1026 \\
\hline Total & & 791 & 442 & 45 & 499 & 42 & 1099 & 693 & 1080 & 534 & 344 & 710 & 660 & 6489 \\
\hline
\end{tabular}

Table 2. Species of Pimplinae sampled with nets sweep in the Parque Nacional da Serra da Canastra/MG in the period of September/2009 to October/2010.

\begin{tabular}{|c|c|c|}
\hline Tribe & Specie & Total \\
\hline \multicolumn{3}{|l|}{ Pimplini } \\
\hline & Neotheronia sp.1 & 1 \\
\hline & Neotheronia sp.2 & 3 \\
\hline & Pimpla sp.1 & 2 \\
\hline \multicolumn{3}{|l|}{ Ephialtini } \\
\hline & Zonopimpla sp.1 & 1 \\
\hline & Zonopimpla sp.2 & 1 \\
\hline
\end{tabular}

According Rizini (1979), above 900 meters typically occurs what we call clenched altitude. Points I and II are exactly in this band (1,468 $\mathrm{m}$ and $1,353 \mathrm{~m}$ ), characterized as a cerrado in this category.

To Rodela (1998) the savanna altitude can be considered as transitions of savanna to rupestrian field, containing plant species of the two formations. Therefore, in these physiognomy there specific endemismo of the flora of the rupestrian fields mixing species of cerrado, attributing atypical character, transitional and biodiverse.

Some authors have reported on their studies several factors responsible for the variation in vegetation mosaic of the Cerrado, such as climate, fire and human actions (CoutinHo 1990; Pivello \& Coutinho 1996; Ratter et al. 1997; Dezzeo et al. 2004). Phytogeographic patterns for the Cerrado have been established also through the studies by different researchers (RATTER \& DARGIE 1992).

RATTER et al. (1996), analyzing 98 Cerrado areas distributed throughout the national territory, encountered a pattern of phytogeographic distribution formed by six groups, which were classified according to locality: a group to south, a group southeast, a group central, a group in the midwest, a group to the north and a group formed by the Cerrado jammed at Amazon. In this work, the climate, and particularly precipitation and the time of the dry season were factors important for the distribution of vegetation of Cerrado, as well as the effect of altitude. Environmental factors cited by these authors are probably also responsible for the formation of different floristic groups presented in the State of Minas Gerais.
Coutinho (1978) emphasizes that the Cerrado is composed of five different vegetation types, which have two extremes, one forest physiognomy called cerradão, where there is predominance of woody vegetation and physiognomy campestral, the grassland, where besides herbaceous vegetation, encountering are also small subshrubs. The others phytophysiognomies, Cerrado sensu stricto and cerrado grassland, are vegetation ecotone between cerradão and grassland.

Eulophidae, Braconidae, Platygastridae, Pteromalidae and Encyrtidae together were the most abundant families, giving $73 \%$ of the total sample (4,743 exemplars).

The abundance of Braconidae was higher than the other families for six months of the collecting, while Eulophidae was highest for four months, already Platygastridae and Pteromalidae for one month each. Eulophidae, Braconidae, Platygastridae and Ichneumonidae occurred in all samples by month (Table 3).

The relative abundance of families at the sample sites is given in Table 3. At Point I the family Eulophidae was most abundant, followed by Encyrtidae and Platygastridae. At Point II the family Braconidae was most abundant, followed by Eulophidae and Platygastridae. At points III and IV Braconidae and Platygastridae were the most abundant families, sequentially, first and second most abundant. Braconids have a high degree of specialization, tending to attack and feed on a very narrow range of hosts (WHARTon et al. 1997). This, and their often specialized suite of biological and behavioral adaptations (SHAw \& HudDLESTON 1991), means the group has strong potential as bio-indicators for biological monitoring (BARBIERI JUNIOR \& PENTEADO-DiAS 2012). The xeromorphic nature of the Cerrado biome favors the 
Table 3. Abundance of individuals and relative abundance (Ra) of parasitoid wasp for each point sample through of technique of sweeping in the Parque Nacional da Serra da Canastra, Minas Gerais.

\begin{tabular}{|c|c|c|c|c|c|c|c|c|c|}
\hline Famílias & Point I & $\operatorname{Ra}(\%)$ & Point II & $\operatorname{Ra}(\%)$ & Point III & $\operatorname{Ra}(\%)$ & Point IV & $\operatorname{Ra}(\%)$ & Total \\
\hline Agaonidae & o & $\mathrm{o}$ & 1 & 0.01 & 1 & 0.01 & 1 & 0.0 & 3 \\
\hline Aphelinidae & 20 & 0.3 & 17 & 0.26 & 22 & 0.33 & 27 & 0.4 & 86 \\
\hline Bethylidae & 15 & 0.23 & 41 & 0.63 & 10 & 0.15 & 72 & 1.1 & 138 \\
\hline Braconidae & 68 & 1.04 & 300 & 4.62 & 327 & 5.03 & 508 & 7.8 & 1203 \\
\hline Ceraphronidae & 7 & 0.1 & 8 & 0.12 & 52 & 0.8 & 63 & 1.0 & 130 \\
\hline Chalcididae & 9 & 0.13 & 19 & 0.29 & 36 & 0.55 & 22 & 0.3 & 86 \\
\hline Diapriidae & 1 & 0.01 & 10 & 0.15 & 9 & 0.13 & 154 & 2.4 & 174 \\
\hline Dryinidae & 3 & 0.04 & 6 & 0.09 & 3 & 0.04 & 5 & 0.1 & 17 \\
\hline Encyrtidae & 120 & 1.84 & 119 & 1.83 & 195 & 3 & 204 & 3.1 & 638 \\
\hline Eucharitidae & 15 & 0.23 & 11 & 0.16 & o & o & 3 & 0.0 & 29 \\
\hline Eulophidae & 227 & 3.49 & 227 & 3.49 & 286 & 4.4 & 469 & 7.2 & 1209 \\
\hline Eupelmidae & 10 & 0.15 & 21 & 0.32 & 54 & 0.83 & 37 & 0.6 & 122 \\
\hline Eurytomidae & 17 & 0.26 & 48 & 0.73 & 110 & 1.69 & 75 & 1.2 & 250 \\
\hline Evaniidae & 7 & 0.1 & 22 & 0.33 & 6 & 0.09 & 25 & 0.4 & 60 \\
\hline Figitidae & 18 & 0.27 & 22 & 0.33 & 39 & 0.6 & 58 & 0.9 & 137 \\
\hline Ichneumonidae & 34 & 0.52 & 59 & 0.9 & 30 & 0.46 & 132 & 2.0 & 255 \\
\hline Megaspilidae & o & o & 3 & 0.04 & o & o & 1 & 0.0 & 4 \\
\hline Mymaridae & 9 & 0.13 & 9 & 0.13 & 29 & 0.44 & 54 & 0.8 & 101 \\
\hline Perilampidae & 2 & 0.03 & 4 & 0.06 & 2 & 0.03 & 14 & 0.2 & 22 \\
\hline Platygastridae & 71 & 1.08 & 157 & 2.4 & 315 & 4.84 & 483 & 7.5 & 1026 \\
\hline Pteromalidae & 41 & 0.63 & 79 & 1.21 & 281 & 4.33 & 266 & 4.1 & 667 \\
\hline Signiphoridae & 7 & 0.1 & 2 & 0.03 & 19 & 0.29 & 9 & 0.1 & 37 \\
\hline Torymidae & 4 & 0.06 & 11 & 0.16 & 14 & 0.21 & 19 & 0.3 & 48 \\
\hline Trichogrammatidae & 1 & 0.01 & 4 & 0.06 & 30 & 0.46 & 12 & 0.2 & 47 \\
\hline Total & 706 & 10.87 & 1200 & 18.49 & 1870 & 28.81 & 2713 & 42 & 6489 \\
\hline
\end{tabular}

Braconidae community whose hosts (which include Lepidoptera, Coleoptera and Diptera) often occupy niches hidden in plant tissues (Cirelli \& Penteado-Dias 2003). The eulophids comprise the largest family of Chalcidoidea (NOYEs 2013), and their biology is also extremely diverse, including ecto- or endoparasitoids of many families and orders of insects (Melo et al. 2012). There are also phytophagous and predatory species (GAUTHIER et al. 2000). Platygastrids are widely represented in all regions of the globe. They parasitize eggs and larvae or larvae of gall midges, or, less often, eggs of cicadas, weevils, some heteropterans, and leaf beetles (KozLOv 1978).

Agaonidae, Megaspilidae and Eucharitidae were the only families that were not found at all sample sites. According to Azevedo \& Santos (2000), these families along with, Aulacidae, Embolemidae, Gasteruptiidae, Heloridae, Leucospidae, Liopteridae, Megalyridae, Ormyridae, Pelecinidae, Perilampidae, Plumariidae, Sclerogibbidae, Scolebythidae, Stephanidae, Tanaostigmatidae are both poorly studied and uncommon in parasitoid wasps inventories.

Indices of dominance, diversity and evenness calculated for the four collection points are shown in Table 4.

For parasitic hymenoptera, differences in collection efforts can influence the number and diversity of captured families (AzEvEDo et al. 2002), and the lack of standardized collection techniques for the group often complicates faunal comparisons between sampled environments, although it does provide an reasonable idea of the proportions of the most abundant groups (Huber
2009).

Consequently, through different collection methods and sampling efforts have been used, it is instructive to compare the current study with others conducted in the Cerrado of Minas Gerais and Goiás. The number of families sampled in this study (24) was greater than that of Marchiori \& Penteado-Dias (2002) using Moericke traps, and PÁDUA \& ZAMPIERON (2012) using the sweeping method, which collected 21 and 20 families, respectively. It is less than the study of MoraEs et al. (2012) who collected a total of 28 families using three collection methods (Malaise and Moericke traps, and sweep net).

Comparing the similarity (Jaccard index) calculated for the few entomofaunal inventories of Cerrado parasitic Hymenoptera (Figure 2), it appears that the present study is most similar to that of Marchiori \& Penteado-Dias (2002) in terms of total number of individuals and the diversity of families. It does not resemble to profile of the study by MoraEs et al. (2012) who collected a fewer individuals, but a greater diversity of families, including some (Ormyridae, Tanaostigmatidae, Ibaliidae and Pelecinidae) that are considered rare in surveys of parasitoids and to be scarce wasps in biological collections (AzEvEdo \& SANTos 2000).

The Cerrado, in general, is home to a great diversity of herbivorous insects, since the phytophysionomic gradient is great, varying from grassland-dominated landscapes to highly forested ones (SANO \& AlmeIDA 1998). Cerrado has a rich flora (RATTER et al. 2003), and thus is a large repository of potential host insects, which in turn attract such families of parasitoids as Braconidae, Eulophidae 
Tabela 4. Diversity indices calculated for the four points made by sweeping through the program PAST 2.00 (HAMMER et al. 2001).

\begin{tabular}{lcccc}
\hline Indices & Point I & Point II & Point III & Point IV \\
\hline Number of families & 23 & 25 & 23 & 25 \\
Individuals & 706 & 1200 & 1870 & 2713 \\
Dominance (D) & 0,1567 & 0,1281 & 0,1086 & 0,1051 \\
Shannon Diversity Index (H') & 2,341 & 2,454 & 2,481 & 2,539 \\
Equitability (J') & 0,7468 & 0,7623 & 0,7914 & 0,7889 \\
\hline
\end{tabular}

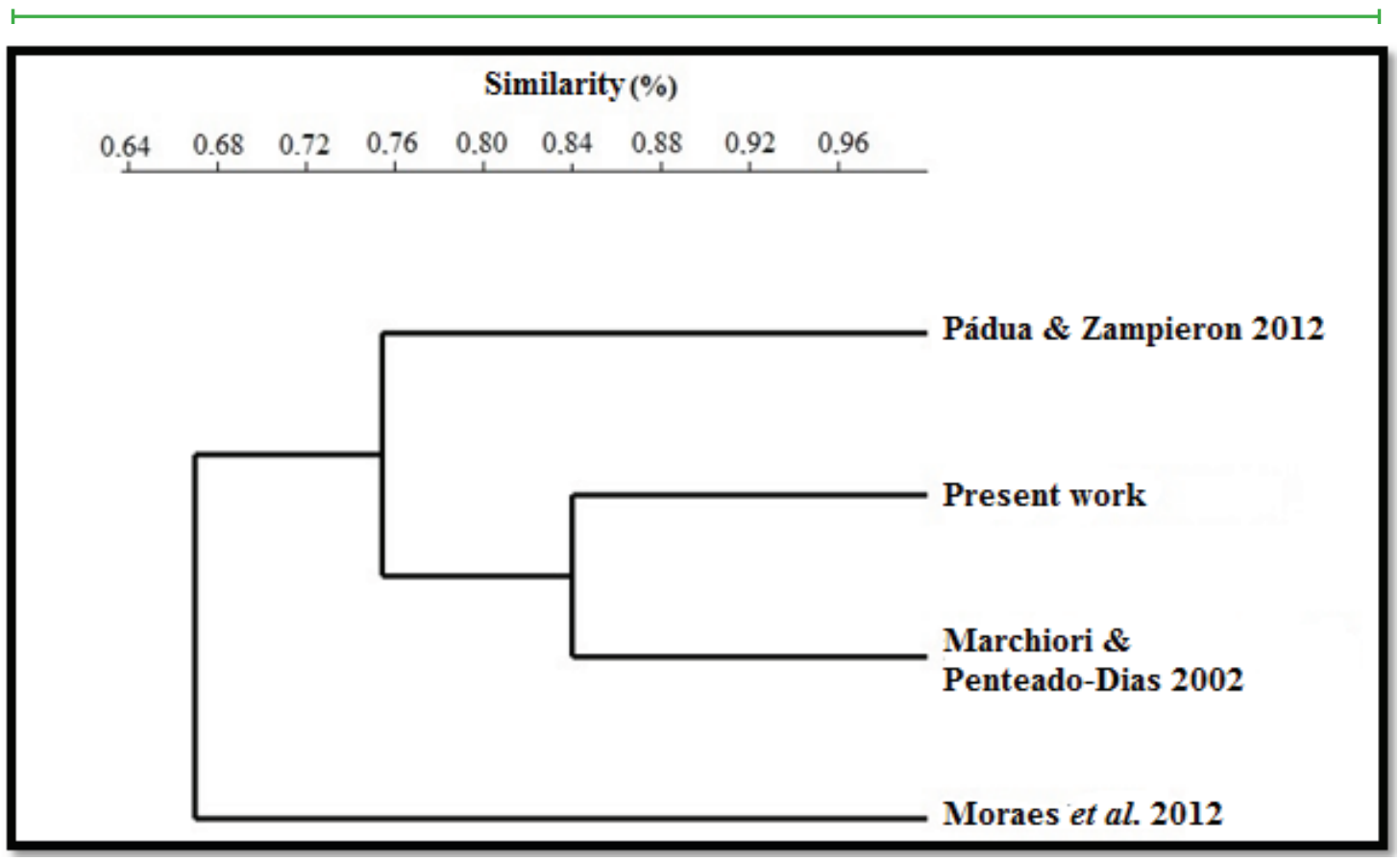

Figura 2. Similarity dendrogram (Jaccard) the works of surveys of families of Hymenopteran parasitoids performed in the Cerrado.

and Pteromalidae (the most well-represented families in this study) as well as other, rarer, families. Nascimento \& PenteadoDiAs (2005) collected Braconidae, Eulophidae, Pteromalidae, Ichneumonidae Eupelmidae that are specifically associated with Cerrado legume species, and which are parasitoids of larvae or pupae of Coleoptera and Lepidoptera living within their fruits.

Several studies have reiterated the importance of the Cerrado in which is dipped the Parque Nacional Serra da Canastra in southwest of Minas Gerais, especially in maintaining tri-trophic relationships there existing. According to MMA (2002), among the Conservation United already created, the Serra da Canastra, undoubtedly, fits into the group of extremely high biological importance, medium anthropic pressure and high biological diversity and interesting relationships.

There are few studies surveys of Hymenoptera parasitoids for the Cerrado, particularly for the Parque Nacional da Serra da Canastra. The current survey showed that the park has a large biodiversity of parasitoid wasps, which, it is hoped will serve as an incentive for future studies of the biological parameters of these insects and their hosts.

\section{ACKNOWLEDGEMENTS}

CNPq for the IC scholarship to D.G. Pádua (Proc.100538/2009-6). For MSc. Cássia I. V. Abreu, Patricia Barboza, Tamara Ferreira, MSc. André L. Martins, Rita C. Oliveira and Felipe Bueno for help in the field and with screening material. The Chico Mendes Institute for Biodiversity Conservation of São Roque de Minas for collection permits. For MSc. Karine Schoeninger the statistical analyzes, Dr. Daniell Fernandes and Dr. Adrian Barnett for his comments and to Dra. Ana Paula Loffredo for confirmation of Pimplinae generic indetification. The National Institute of Science and Technology of Hymenoptera parasitoids of the Brazilian Southeast Region - South East INCT HYMPAR.

\section{REFERENCES}

Abreu, C.I.V. \& S.L.M. Zampieron, 2009. Perfil da Fauna de Hymenoptera Parasítica em um Fragmento de Cerrado pertencente ao Parque Nacional da Serra da Canastra - MG, a partir de duas Armadilhas de Captura. Ciência et Praxis, Brasil, 2: 61-68.

Alencar, I.D.C.C., F.B. Fraga, M.T. Tavares \& C.O. Azevedo, 2007. Perfil da fauna de vespas parasitoides (Insecta, Hymenoptera) em áreas de Mata Atlântica do Parque Estadual da Pedra Azul, Domingos Martins, Espírito Santo, Brasil. Arquivos do Instituto Biológico, São Paulo, 74: 111-114.

Azevedo, C.O. \& H.S. Santos, 2000. Perfil da fauna de himenópteros parasitoides (Insecta, Hymenoptera) em uma área de Mata Atlântica da Reserva Biológica de Duas Bocas, Cariacica, ES, Brasil. Boletim do Museu de Biologia Mello Leitão, série nova, 11/12: 116-126.

Azevedo, C.O., R. Kawada, M.T. Tavares \& N.W. Perioto, 2002. Perfil da fauna de himenópteros parasitoides (Insecta, Hymenoptera) em uma área de Mata Atlântica do Parque Estadual da Fonte Grande, Vitória, ES, Brasil. Revista Brasileira de Entomologia, 46:133-137.

Azevedo, C.O., M.S. Corrêa, F.T. Gobbi, R. Kawada, G.O. Lanes, A.R. Moreira, E.S. Redighieri, L.M. Santos \& C. Waichert, 2003. Perfil das famílias de vespas parasitóides (Hymenoptera) em uma área de Mata Atlântica da Estação Biológica de Santa Lúcia, Santa Tereza, ES, Brasil. Boletim Museu de Biologia Mello Leitão, 16: 39-46.

Barbieri Junior, C.A. \& A.M. Penteado-Dias, 2012. Braconidae (Hymenoptera) fauna in native, degraded and restoration areas of the Vale do Parnaíba, São Paulo state, Brazil. Brazilian Jounal Biology, 72: 305-310.

Cirelli, K.R.N. \& A.M. Penteado-Dias, 2003. Análise da riqueza da fauna de Braconidae (Hymenoptera, Ichneumonidae) em remanescentes naturais da Área de Proteção Ambiental 
(APA) de Descalvado, SP, Revista Brasileira de Entomologia, 47: 89-98.

Coutinho, L., 1978. O conceito de cerrado. Revista Brasileira de Botânica, 1: 17-23.

Coutinho, L., 1990. Fire in the ecology of the Brazilian cerradão p. 82-105. In: Goldammer, J.G. (Ed.). Fire in the tropical biota. Springer-Verlag Berlin Heidelberg, 491p.

Dall'Oglio, O.T., J.C. Zanuncio, C.O. Azevedo \& A.G.B. Medeiros, 2000. Survey of the Hymenoptera Parasitoids in Eucalyptus grandis and in a native vegetation area in Ipara, State of Minas Gerais, Brazil. Anais da Sociedade Entomológica do Brasil 20: 583-588.

Dezzeo, N., Chacón, N., Sanoja, E., Picón, G., 2004. Changes in soil properties and vegetation characteristics along a forestsavanna gradient in southern Venezuela. Forest Ecology and Management, 200: 183-193.

Dorfey, C., K. Schoeninger \& A. Köhler, 2011. Levantamento das familias de himenópteros parasitoides associados ao cultivo de tabaco (Nicotiana tabacum L.) em Santa Cruz do Sul e Lagoão, Rio Grande do Sul, Brasil. Arquivos do Instituto Biológico, São Paulo, 78: 449-451.

Eiten, G., 1972. The Cerrado Vegetation of Brazil. The Botanical Review 38: 201-327.

Feitosa, M.C.B., R.B. Querino \& A.L. Henriques, 2007. Perfil da fauna de vespas parasitoides em reserva florestal na Amazônia, Brasil. Entomotropica 22: 37-43.

Fernández, F., 2006. Sistemática de los himenópteros de La Región Neotropical: Estado Del conocimiento y perspectivas, p. 07-36. In: Fernández, F. \& Sharkey, M.J. (Eds) Introducción a los Hymenoptera de La Región Neotropical. Bogotá: Sociedad Colombiana de Entomologia y Universidad Nacional de Colombia, 893p.

Ferreira, F.Z., L.C.P. Silveira \& M.M. Haro, 2013. Famílias de himenópteros parasitoides em cultivos orgânicos de café em Santo Antônio do Amparo, MG, Brasil. Coffee Science, 8: $1-5$.

Fitton, M.G., M.R. Shaw \& I.D. Gauld, 1988. Pimpline ichneumonflies. Handbooks for the Identification of British Insects, 7: 1-110.

Gauthier, N., J. LaSalle, D.L.J. Quicke \& H.C.J. Godfray, 2000. Phylogeny of Eulophidae (Hymenoptera: Chalcidoidea) with a reclassification of Eulophinae and the recognition that Elasmidae are derived eulophids. Systematic Entomology, 25: 521-539.

Gauld, I.D., 1991. The Ichneumonidae of Costa Rica, I. Memoirs of the American Entomological Institute, Gainesville, 47, $589 \mathrm{p}$.

Gauld, I.D., J.A.U. Gómez \& P.S. Hanson, 1998. Guía de los Pimplinae de Costa Rica (Hymenoptera: Ichneumonidae). Revista de Biologia Tropical, 46: 1-189.

Hammer, O., D.A.T. Harper \& P.D. Ryan, 2001. PAST: Paleontological statistics software package for education and data analysis. Palaeontologia Electronica, 4: 9p. Available in: <http://folk.uio.no/ohammer/past $>$. [Accessed: o8.16.2013]

Hills, T.L. \& R.E. Randall (eds.), 1968. The ecology of the forest/ savanna boundary: Proceedings of the I.G.U. humid tropics symposium, Venezuela, 1964. Montreal, Canada: Department of Geography, McGill University, 128p.

Huber, J.T., 2009. Biodiversity of Hymenoptera, p. 303-323. In: Foottit, R.G., Adler, P.H. (Eds) Insect biodiversity: science and society. London: Blackwell, 656p.

IBDF, 1981. Plano de Manejo do Parque Nacional da Serra da Canastra. Brasília, Brasiliana Ltda, 81p.

Kumagai, A.F., 2002. Os Ichneumonidae (Hymenoptera) da Estação Ecológica da Universidade Federal de Minas Gerais, Belo Horizonte, com ênfase nas espécies de Pimplinae. Revista Brasileira de Entomologia, 46: 189-194.

Kozlov, M.A., 1978. Superfamily Proctotrupoidea, p. 538-664. In: Medvedev, G.S. (Ed.): Identification of the insects of the European part of the USSR. Vol. 3, part 2. Nauka, Leningrad,
$1,341 \mathrm{p}$.

MMA, 2002. Biodiversidade Brasileira: avaliação e identificação de áreas e ações prioritárias para a conservação, utilização sustentável e repartição de benefícios da biodiversidade brasileira. Secretaria de Biodiversidade e Florestas, MMA, Brasília, DF.

MMA/IBAMA, 2005. Plano de Manejo: Resumo Executivo do Parque Nacional da Serra da Canastra. Brasília. 104p.

Marchiori, C.H. \& A.M. Penteado-Dias, 2002. Famílias de parasitoides coletadas em áreas de mata e pastagens no município de Itumbiara, Estado de Goiás. Acta Scientiarum, 24: 897-899.

Melo, G.A.R., A.P. Aguiar \& B.R. Garcete-Barrett, 2012. Hymenoptera, p. 553-623. In: Rafael, J.A., G.A.R. Melo, C.J.B. Carvalho, S.A. Casari \& R. Constantino (Eds). Insetos do Brasil: Diversidade e taxonomia. Holos. Ribeirão Preto. Cap. 35, 813p.

Moraes, A.B., P. Perre \& J.F. Sobczak, 2012. Fauna de Vespas Parasitoides (Insecta, Hymenoptera) Coletadas em um Fragmento de Cerrado, Jataí, Goiás, Brasil. Arquivos do Instituto Biológico, 79: 437-441.

Nascimento, A.R. \& A.M. Penteado-Dias, 2005. A fauna de Hymenoptera associada às espécies de leguminosas que ocorrem em áreas de Cerrado. Arquivos do Instituto Biológico, 72: 1-64.

Noyes, J.S., 2013. Universal Chalcidoidea Database. World Wide Web electronic publication. Available in: <http://www.nhm. ac.uk/chalcidoids $>$. [Accessed: 01.21.2014].

Oksanen, J., F.G. Blanchet, R. Kindt, P. Legendre, P.R. Minchin, R.B. O’Hara, G.L. Simpson, P. Solymos, M. Stevens \& H. Wagner, 2013. Vegan: Community Ecology Package. R package version 2.0-1.0.

Pádua, D.G. \& S.L.M. Zampieron, 2012. Inventário da fauna de Hymenoptera Parasitóides Coletados com Redes de Varredura em um Fragmento da Serra da Babilônia, no Sudoeste do Estado de Minas Gerais. EntomoBrasilis, 5: 211-216.

Perioto, N.W., R.I.R. Lara, J.C.C. Santos \& A. Selegatto, 2002a. Himenópteros parasitóides (Insecta, Hymenoptera) coletados na cultura de algodão (Gossypiumhirsutun L.) (Malvaceae), no município de Ribeirão Preto, SP, Brasil. Revista Brasileira de Entomologia, 46: 165-168.

Perioto, N.W., R.I.R. Lara, J.C.C. Santos \& T.C. Silva, 2002b. Himenópteros parasitóides (Insecta, Hymenoptera) coletados na cultura de soja (Glycinemax (L.) Merril) (Fabaceae), no município de Nuporanga, SP, Brasil. Revista Brasileira de Entomologia, 46: 185-187.

Perioto, N.W. \& R.I.R. Lara, 2003. Himenópteros parasitoides (Insecta: Hymenoptera) da Mata Atlântica I. Parque Estadual da Serra do Mar, Ubatuba, SP, Brasil. Arquivos do Instituto Biológico, São Paulo, 70: 441-445.

Perioto, N.W., R.I.R. Lara \& A. Selegatto, 2005. Himenópteros parasitóides da Mata Atlântica II. Núcleo Grajaúna, Rio Verde da Estação Ecológica Juréia-Itatins, Iguape, SP, Brasil. Arquivos do Instituto Biológico, São Paulo, 72: 81-85.

Perioto, N.W., R.I.R. Lara, A. Selegatto \& E.S. Luciano, 2004. Himenópteros parasitóides (Insecta, Hymenoptera) coletados na cultura de café Coffea arabica L. (Rubiaceae) em Ribeirão Preto, SP, Brasil. Arquivos do Instituto Biológico, São Paulo, 71: 41-44.

Perioto, N.W., R.I.R. Lara, A.M. Vacari, L. Favoreto, N.R. Chagas Filho \& R. Pessoa, 2008. Diversidade de himenópteros parasitoides (Hymenoptera) na Estação de Jataí, Luiz Antonio, SP, Brasil. Revista de Agricultura (Piracicaba), 83: 125-133.

Pivello, V.R \& Coutinho, L.M. 1996. A qualitative successional model to assist in the management of Brazilian Cerrado. Forest Ecology and Management, 87: 127-138.

R Development Core Team, 2014. R: A language and environment for statistical computing. $\mathrm{R}$ Foudation for Statistical Computing, Vienna, Austria, ISBN 3-900051-07-0. Available in: <http://www.R-project.org>. [Accessed: 05.16.2014]. 
Ratter, J.A. \& T.C.D. Dargie, 1992. An analysis of the floristic composition of 26 cerrado areas in Brazil. Edinburgh Journal of Botany, 49: 235-250.

Ratter, J.A., S. Bridgewater, R. Atkinson \& J.F. Ribeiro, 1996. Analysis of the floristic composition of the Brazilian cerradão vegetation II: Comparison of the woody vegetation of 98 areas. Edinburgh Journal of Botany, 53: 153-180.

Ratter, J.A., S. Bridgewater \& J.F. Ribeiro, 2003. Analysis of the floristic composition of the Brazilian Cerrado vegetation III: comparison of the woody vegetation of 376 areas. Edinburgh Journal of Botany, 60: 57-109.

Ratter, J.A.; Ribeiro, J.F. \& Bridgewater, S. 1997. The brazilian cerrado vegetation and threats to its biodiversity. Annals of Botany 80: 223-230.

Rizini, C.T., 1979. Tratado de Fitogeografia do Brasil: Aspectos Sociológicos e Florísticos. São Paulo. HUCITEC/EDUSP. Vol. 2, 374p.

Rodela, L.G. 1998. Cerrados de Altitude e Campos Ruprestres do Parque Estadual de Ibitipoca, Sudeste de M. Gerais: Distribuição e Florística por subfisionomias de vegetação. Revista do Departamento de Geografia, 12: 163-189.

Sano, S.M. \& S.P. Almeida (Eds), 1998. Cerrado: ambiente e flora. Planaltina: Embrapa-CPAC. 556p.

Sharkey, M.J., 2007. Phylogeny and Classification of Hymenoptera. In: Zhang, Z.Q. \& W.A. Shear (Eds.). Linnaeus
Tercentenary. Progress in Invertebrate Taxonomy. Zootaxa, 1668: 1-766.

Shaw, M.R. \& T. Huddleston, 1991. Classification and Biology of Braconid Wasps (Hymenoptera. Braconidae). Handbooks for the Identification of British Insects, 7: 1-126.

Southwood, T.R.E., 1978. Ecological methods, with particular reference to the study of insect populations. Chapman \& Hall, London, 2 ed., 524p.

Souza, L., S.M.P. Braga \& M.J.O. Campos, 2006. Himenópteros parasitoides (Insecta, Hymenoptera) coletados em área agrícola de Rio Claro, SP, Brasil. Arquivos do Instituto Biológico, São Paulo, 73: 465-469.

Wharton, R.A.; P.M. Marsh \& M.J. Sharkey, 1997. Manual of the New World genera of the family Braconidae (Hymenoptera). Washington, DC, The International Society of Hymenopterists. Special Publications 1, 439p.

\section{Received in: 05/20/2014 \\ Accepted in: 09/17/2014}

$* * * * * * * * *$

\section{Suggested citation:}

Pádua, D.G., S.L.M. Zampieron \& J.F. Nunes, 2014. Composition of the Families of Parasitoids Wasp in the Parque Nacional da Serra da Canastra, Minas Gerais, Brazil. EntomoBrasilis, 7 (3): 199-206.

Available in: doi:10.12741/ebrasilis.v7i3.443
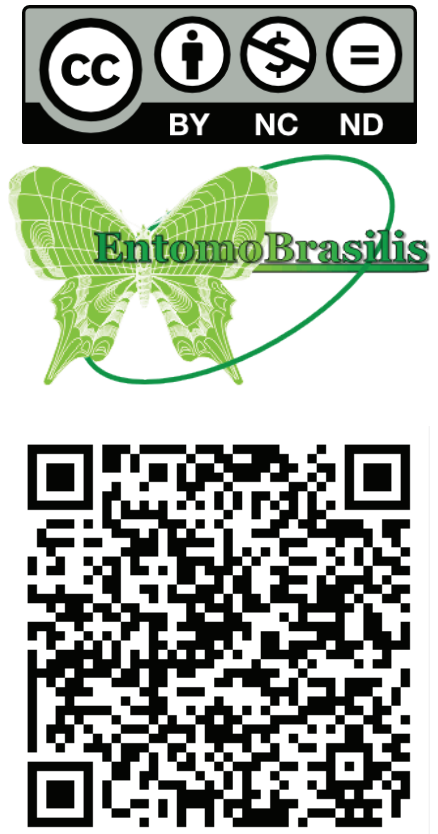